\title{
AUTOMATED TOOL FOR THE EXTRACTION OF THE SURFACE PONDS BASED ON LIDAR DATA
}

\author{
Kinga IVAN ${ }^{1}$, Daria GAGACKA ${ }^{2}$, Paulina MATECKA ${ }^{2}$
}

DOI: $10.21163 / G T \_2018.132 .07$

\begin{abstract}
:
The risk associated with urban flooding is expected to increase significantly in the future as a result of urbanization and climate change. It is therefore necessary to develop new strategies and tools for managing urban floods. With the increase of impervious surfaces in urban areas, due to rainfall rainwater on the surface tends to accumulate in ponds. The delimitation of these areas is important because they outline possible areas vulnerable to flooding. In this paper we have proposed the automatic identification of these ponds by developing an algorithm using the Model Builder tool of ArcGIS program. The model was applied to LiDAR data for the city of Wrockaw in Poland, a city with a high risk of urban flooding. The Model Builder tool successfully delimits the ponds at the ground surface based on a Digital Elevation Model (DEM), without being necessary a manual intervention, thus saving time and energy for the users.
\end{abstract}

Key-words: Surface pond; Automatic tool, Urban flooding, LiDAR, Wrocław.

\section{INTRODUCTION}

Climate change, undersized sewerage network, urban sprawl are only a few factors that increase the risk of flooding in urban areas. Due to urbanization areas occupied with constructions, roads, parking lots, concrete or asphalt paved surfaces have increased (Ivan, 2015; Benedek \& Ivan, 2018). On these surfaces, the water from the heavy rains tends to drain following the steepest slope, and in the low land areas tends to accumulate in the ponds of different sizes (Haidu \& Ivan, 2016a). Ponds outline potential areas vulnerable to urban flooding (Maksimovic et al., 2009), and the identification of these areas is important in flood management.

Lately a series of flood analysis models have been developed, such as: overland flow model which involves a modeling of flow pathways and ponds on the ground surface (Boonya-aroonnet, 2008; Peng et al., 2018), or coupled models - 2D which integrates overland and underground flow model (Chen et al., 2005; Dey \& Kamioka, 2006; Maksimovic et al., 2009; Son et al., 2016). However, many of the developed models do not take into account the anthropogenic influences on the ground surface such as buildings, roads or land configuration (Peng et al., 2018). The wide availability of different digital data such as DEM (Digital Elevation Model), DSM (Digital Surface Model), LiDAR (Light Detection and Ranging) from low-resolution to high-resolution elevation Digital Elevation Model make it possible to delimit the surface ponds with a high precision and accuracy. LiDAR data, however, offers the possibility of delimiting these areas taking into account the existing obstacles on the ground surface (buildings, fences or road curbs) which directly influence the water draining and water accumulation on the ground surface (Haidu \& Ivan, 2016a).

\footnotetext{
${ }^{1}$ Babeş-Bolyai University, 400006 Cluj-Napoca, Romania, kinga.ivan@ubbcluj.ro;

${ }^{2}$ Nicolaus Copernicus University, 87-100 Toruń,Poland,daria_gag@wp.pl, paulina.matecka95@gmail.com;
} 
The present paper describes a new algorithm in order to automatically extract the surface ponds within an urban area (Wrocław, Poland) based on a Digital Elevation Model (LiDAR). The manual extraction of information regarding the ponds require a lot of time, energy and expertise in the field. The developed model offers the possibility of improvement of the already existing overland flow model, it can be helpful and can be used by policy makers from local level for changing and improving strategies on water management.

\section{STUDY AREA AND DATA}

In this paper model application has been made for the city of Wrocław, Poland (Fig. 1), which presents a high risk of urban flooding. Wrocław is located in the central part of the Silesian Lowland macro-region with a population of 638586 inhabitants (Local Data Bank of Poland, 2018) and an area of $292.92 \mathrm{~km}^{2}$. In its composition the city includes smaller geographical units in the rank of mesoregions: Wrocław Glacial Valley, Wrocław Plain and Oleśnicka Plain. The average width of the glacial valley in the city is $7-10 \mathrm{~km}$. Wrocław Plain stretches between Wrocław Glacial Valley and Sudetes Foreland. It stretches on the left bank of the Oder, between the valleys of Oława and Strzegomka. The highest elevation of the city is $155 \mathrm{~m}$ and the lowest is $105 \mathrm{~m}$ (Kondracki, 2009).
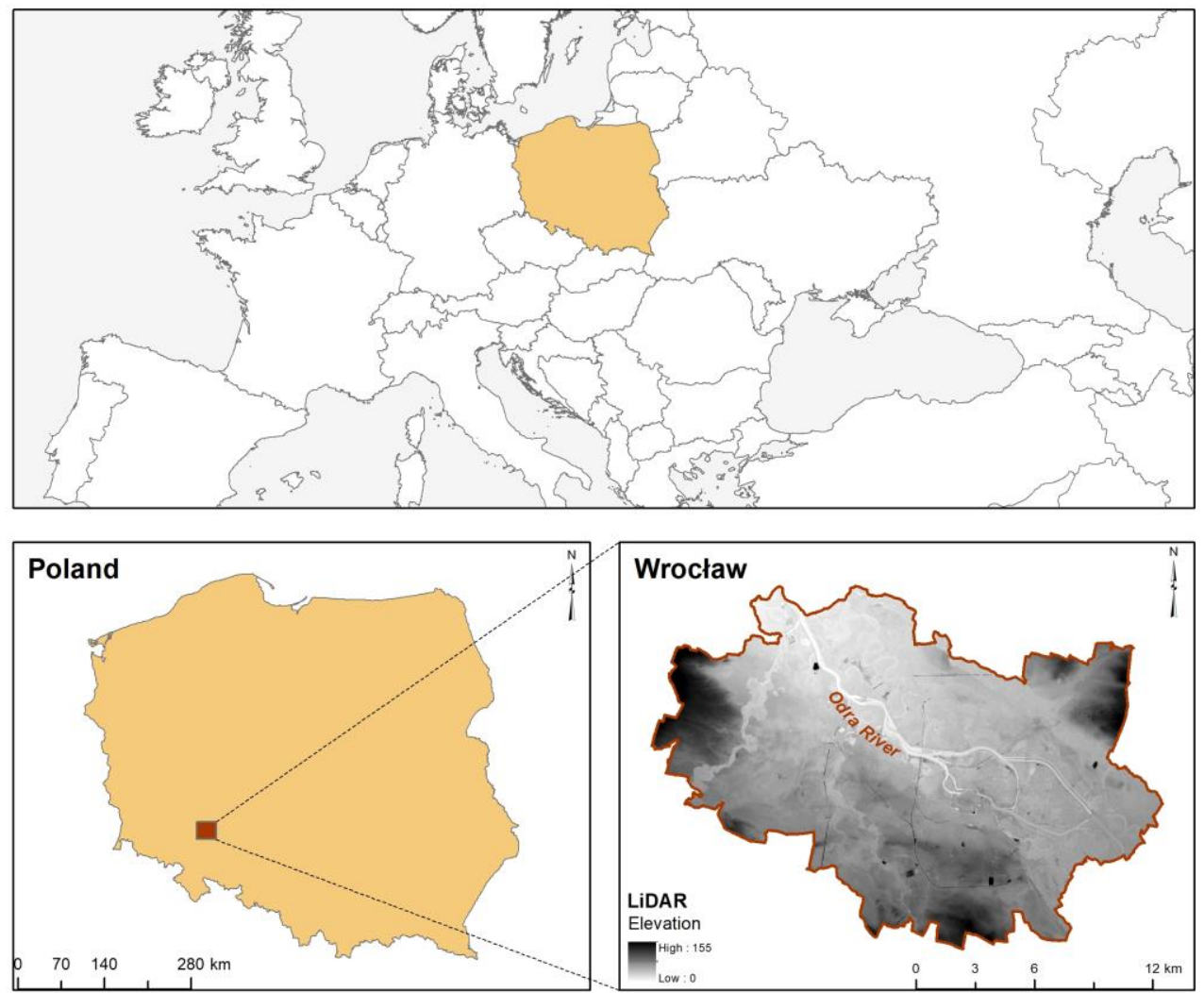

Fig. 1. Location of the study area (Source: authors). 
The Odra, the second largest river in Poland, has enormous socio-economic importance for Wrocław. It affects the development of business, social integration and shaping the city's space. Odra divides the city into right and left-bank areas with uneven population. About 1/3 of the population of Wroclaw lives right bank of the Oder. On the section of the Odra flowing through Wrocław, strategic hydrotechnical constructions are located, including the Flood Canal, ensuring the main protection of the city through floods (SUiKZP, 2018).

During the flood of the millennium that hit Central Europe in July 1997, the waters of the Oder and its tributaries, including Bóbr, Bystrzyca, Kaczawa, Kwisa, Mała Panew, Nysa Kłodzka, Nysa Łużycka, Olza, Oława, Ślęza and Widawa flooded Wrocław. The flood waters of the Odra River broke into the city on July 12, 1997, and finally gave way in August 6. In Wroclaw, the flood of the millennium was particularly difficult because two flood waves overlapped: the Odra and Widawa rivers (Miskiewicz, 2007).

The model developed in this paper allows the extraction of surface ponds using as input data only a Digital Elevation Model. On a global scale elevation models with different resolution and precision are available. Of these models we can mention the SRTM digital elevation model with a spatial resolution of $90 \mathrm{~m}$, ASTER data set with a spatial resolution of $30 \mathrm{~m}$, both with low spatial resolution and precision in multiple regions (Mukul et al., 2017). Based on LiDAR data, with a high spatial resolution a detailed analysis of the ponds at the ground surface can be made, taking into account the existing objects from the ground surface as well.

In this paper surface ponds have been extracted based on a LiDAR digital elevation model with a $1 \mathrm{~m}$ spatial resolution, obtained from CODGiK (2012). Lidar data have been used successfully by Hanus and Evans (2015) in a similar study in order to detect the medieval water reservoirs in Angkor.

\section{METHODOLOGY}

In the developed model GIS technology and a Digital Elevation Model has been used for the extraction of ponds. The tools available in the ArcGIS10.4 toolbox and ArcGIS Model Builder allowed us to build and automate the model. Among the tools available within ArcGIS toolbox especially tools of the Spatial Analyst extension have been used.

The methodology for extracting surface ponds have assumed the following operations (Haidu \& Ivan, 2016a), illustrated in Fig.4:

a) the delimitation of representative ponds

In the first part of the model we have focused on outlining the representative areas for each pond or knoll that exist in the study area.

- At first this stage implied the identification of the lowest and highest areas of the land, based on the elevation model;

- Subsequently all the adequate concentric contours for these areas have been delimited using the Contour function within the Spatial Analyst extension of ArcGIS program;

- Concentric contours thus obtained have been transformed into polygons, and in order to obtain a single representative polygon for each pond or knoll, the Dissolve and Multipart to Singlepart functions have been used; 


\section{b) pond detection algorithm}

The second part of the model consisted in the identification and separation of the ponds from knolls.

- Representative polygons for each pond or knoll have been transformed in Line feature type;

- Based on the Digital Elevation Model and with the help of the Zonal Statistics function, the average, maximum, and minimum altitude was calculated for each Line feature, as well the average altitude for each polygon;

- Using the expression (Fig.2) the detection of surface ponds and knolls have been used;

Input:

Line mean altitude ( $\left.\mathrm{L}_{\text {mean }}\right)$

Line maximum altitude $\left(\mathrm{L}_{\max }\right)$

Line minimum altitude $\left(\mathrm{L}_{\mathrm{min}}\right)$

Polygon mean altitude $\left(\mathrm{P}_{\text {mean }}\right.$

Algorithm:

$$
\begin{aligned}
& \text { if }\left(\mathrm{P}_{\text {mean }}\right)>\left(\mathrm{L}_{\text {mean }}\right) \text { then } \\
& \quad \mathrm{x}=\left(\mathrm{L}_{\text {min }}\right) \\
& \text { else } \\
& \quad \mathrm{x}=\left(\mathrm{L}_{\text {max }}\right) \\
& \text { end if }
\end{aligned}
$$

Fig. 2. The algorithm used in the delimitation of knolls and ponds.

The identification of these areas implied the following: where the average value of the cell from the polygons was higher than the value $\mathrm{L}_{\text {mean }}$, the $\mathrm{L}_{\min }$ has been taken into consideration in the delimitation, and where the value $\mathrm{P}_{\text {mean }}$ was smaller than $\mathrm{L}_{\text {mean }}, \mathrm{L}_{\max }$ has been taken into consideration in the delimitation (Fig. 3).
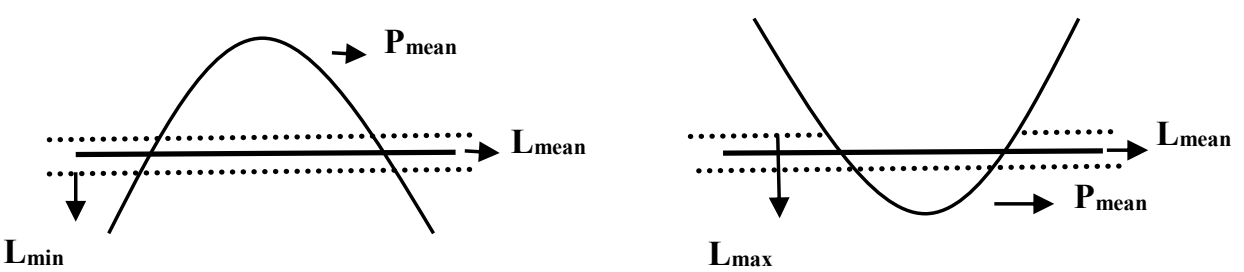

Fig. 3. Illustration of the delimitation of knolls and ponds (source: Haidu \& Ivan, 2016a).

Later, following the conversion of these areas into raster files, using the Cut Fill tool, based on the Digital Elevation Model, the separation of the surface ponds of knolls has been carried out. 


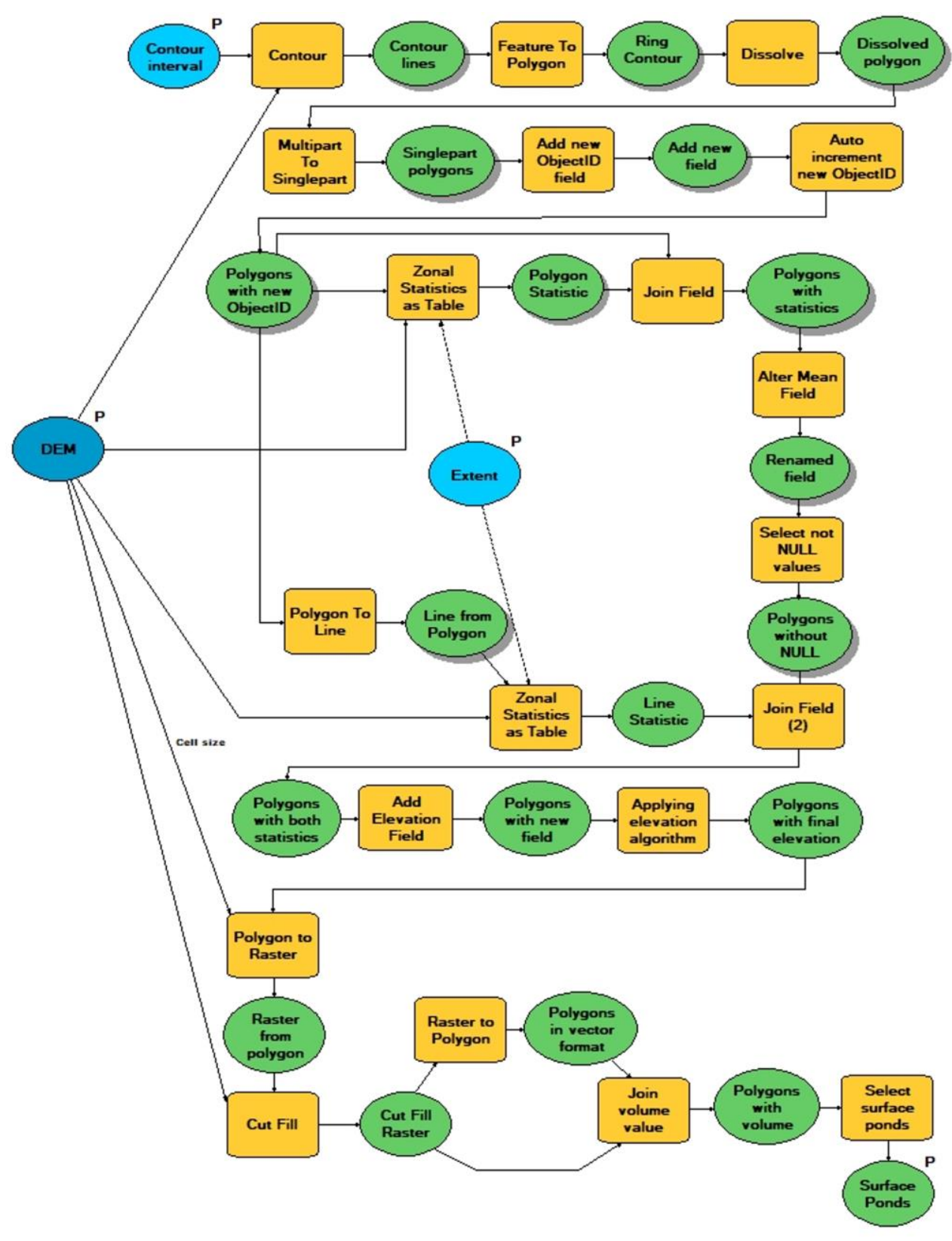

Fig. 4. Model Builder diagram showing the workflow to extract the surface ponds from the Digital Elevation Model (Source: authors). 


\section{RESULTS AND DISCUSSIONS}

The model developed and presented in the present paper allows users to quickly and automatically delimit surface ponds using as input data only a Digital Elevation Model. Due to the large number of existing ponds on the ground, manual measurement or manual mapping of these ponds would consume a lot of time and energy.

In the city of Wrocław we have identified over 200000 ponds using the developed tool. Following their verification, of the total number of ponds detected, all of them have been positively identified. The ponds thus obtained have been filtered, those with a surface smaller than $100 \mathrm{~m}^{2}$ have been considered insignificant in this study and have been eliminated. By filtering the pond areas from the total number of 219923 ponds, 210124 ponds have been eliminated, resulting in the end a number of 9799 ponds with a surface greater than $100 \mathrm{~m}^{2}$ (Fig.5).
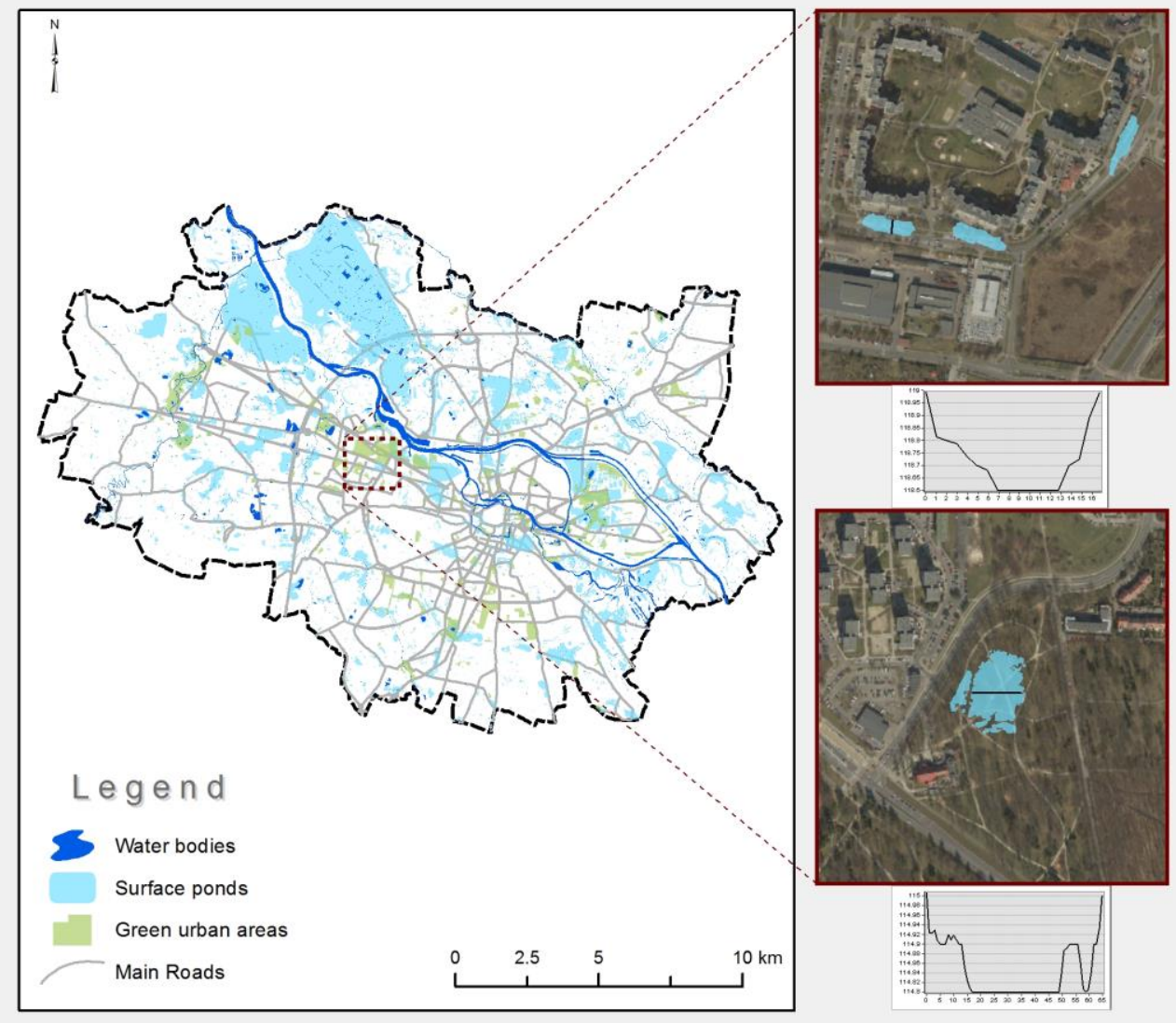

Fig. 5. Illustration of surface ponds identified in the city of Wrocław, Poland, based on LiDAR data (Source: authors).

From the remaining 9799 ponds, 68 ponds were identified with high influence (the ponds surface greater than $0.1 \mathrm{~km}^{2}$ ), 382 ponds that have medium influence (the ponds surface between $0.01 \mathrm{~km}^{2}$ and $0.1 \mathrm{~km}^{2}$ ), 1664 ponds with low influence (the ponds surface between $0.001 \mathrm{~km}^{2}$ and $0.01 \mathrm{~km}^{2}$ ) and 7685 ponds that have very low influence (the ponds 
surface between $100 \mathrm{~m}^{2}$ and $1000 \mathrm{~m}^{2}$ ). After analyzing and interpreting the data, we have found that these ponds are likely to occur near the rivers, green urban areas or road intersections.

The automated tool developed for filtering Lidar data can detect the ponds with different depths and dimensions based on a DEM, but it is necessary to classify them according to their surface which could disrupt the daily activity or transport. Depending on how high/medium/low limits are sets, the automated tool developed in the present study can be applied to other urban areas.

This tool has been designed to automatically identify natural or artificial surface ponds which are capable of retaining water during or after rainfalls. These temporary water storage nodes (Boonya-aroonnet, 2008) can be viewed as areas prone to flooding. The tool developed in the study has been successfully tested in several subwatersheds, such as those in Cluj-Napoca, Romania (Haidu \& Ivan, 2016a; Haidu \& Ivan, 2016b) as well as in France (Haidu \& Ivan, 2016c). Therefore we can say that this tool is reliable and can be used by policy makers in order to find and implement measures to prevent urban flooding that can have major effects on the population.

Early knowledge of these areas can help local authorities to develop new flood management strategies. From effective flood control techniques we can mention: detention basins which can help reduce the peak flow (Ardeshir et al., 2013), green roofs, separated sewerage systems or paving the parking lots with permeable pavements which allow the pluvial water infiltration into the soil (Haidu \& Ivan, 2015).

\section{CONCLUSIONS}

Urban pluvial flooding, often caused by the exceeded the capacity of the drainage system, or the clogging of drain holes, is a rapid and direct consequence of precipitations. They appear unexpectedly, without prior warning, most often in areas which are not prone to flooding. Their consequences can have pronounced effects on the population, on the environment and can sometimes lead to major economic losses.

The model developed in the present paper allows the early identification and knowledge of possible areas vulnerable to floods - surface pond - and may stand as a valuable tool for local decision-makers, in order to improve water management strategies. After analyzing the surface ponds we have found that the ponds having a surface greater than $100 \mathrm{~m}^{2}$ could cause problems during heavy rainfalls to traffic or to civic life, if the sewer system is blocked by certain objects or materials or when the sewer system is under pressure. The model automation offers the user the ability to easily use it, saving time and energy and can underpin the improvement of other existing models.

\section{R E F E R E N C E S}

Ardeshir, A., Salari, K., Jalilsani, F., Behzadian, K. \& Mousavi, S. J. (2013) Urban Flood Mitigation By Development Of Optimal Detention Ponds In Urban Areas: A Case Study. In International Conference on Flood Resilience: Experiences in Asia and Europe, 5-7 September 2013, Exeter, United Kingdom.

Benedek, J. \& Ivan, K. (2018) Remote sensing based assessment of variation of spatial disparities. Geographia Technica, 13 (1), 1-9.

Boonya-aroonnet, S. (2008) Applications of the innovative modelling of urban surface flooding in the UK case studies. In 11th International Conference on Urban Drainage, Edinburgh, UK. 
Chen, A. S., Hsu, M. H., Chen, T. S. \& Chang, T. J. (2005) An integrated inundation model for highly developed urban areas. Water Science \& Technology, 51(2), 221-229.

CODGiK (2012). - Centralny Ośrodek Dokumentacji Geodezyjnej i Kartograficznej (Central Documentation Centre of Geodesy and Cartography), Numeryczne dane wysokościowe (Numerical elevation data). Available from: from: www.codgik.gov.pl.

Dey, A. K. \& Kamioka, S. (2006) An integrated modelling approach to predict flooding on urban basin. 7th Int.Conf. on Urban Drainage Modelling and 4th Int. Conf. on Water Sensitive Urban Design, Melbourne, 2, 259-266.

Haidu, I. \& Ivan, K. (2015) Rainwater management aiming to improve the quality of urban surface runoff. Studia Universitatis Babes-Bolyai Geographia, LX , 2, 35-44.

Haidu, I. \& Ivan, K. (2016a) Ponds delineation in various urban landforms. Case study for ClujNapoca, Romania. Environmental Engineering and Management Journal, 15(6), 1379-1386.

Haidu, I. \& Ivan, K. (2016b) The assessment of the impact induced by the increase of impervious areas on surface runoff. Case study the city of Cluj-Napoca, Romania. Carpathian Journal of Earth and Environmental Sciences, 11(2), 331-337.

Haidu, I. \& Ivan, K. (2016c) Urban runoff pathways and surface water volumes evolution. Case study: Bordeaux 1984-2014, France. Houille Blanche-Revue Internationale de l eau, 5, 51-56.

Hanus, K. \& Evans, D. (2015) Imaging the waters of Angkor: a method for semi-automated pond extraction from LiDAR data. Archaeol. Prospect, 23, 87-94.

Ivan, K. (2015) The spatio-temporal analysis of impervious surfaces in Cluj-Napoca, Romania. Geographia Technica, 10 (2), 50-58.

Kondracki, J. (2009) Geografia regionalna Polski. PWN, Warszawa, Poland.

Local Data Bank of Poland (2018). - Central Statistical Office of Poland. Available form: https://bdl.stat.gov.pl/BDL/start.

Maksimovic, C., Pradanovic, D., Boonya-Aroonnet, S., Leitao, J. P., Djordjevic, S. \& Allitt, S. I. (2009) Overland flow and pathway analysis for modelling of urban pluvial flooding. Journal of Hydraulic Research, 47(4), 512-523.

Miskiewicz, M. (2007). - Powódź tysiąclecia - bilans dziesięciolecia. Money 12 July 2007. Available from:www.money.pl/gospodarka/raporty/artykul/powodz;tysiaclecia;;bilans;dziesieciolecia,135, 0,252551.html. [Accessed September 2018].

Mukul, M., Srivastava, V., Jade, S. \& Mukul, M. (2017) Uncertainties in the Shuttle Radar Topography Mission (SRTM) Heights: Insights from the Indian Himalaya and Peninsula. Sci. Rep., 7, 41672.

Peng, G. Q., Lu, F. Q., Song, Z. Y. \& Zhang, Z. (2018) Key Technologies for an Urban Overland Flow Simulation System to Support What-If Analysis. Journal of Water Resource and Protection, 10, 699-724.

Son, A.-L., Kim, B. \& Han, K.-Y. (2016) A Simple and Robust Method for Simultaneous Consideration of Overland and Underground Space in Urban Flood Modeling. Water, 8, 494.

SUiKZP (2018). - Studium uwarunkowań i kierunków zagospodarowania przestrzennego Wrocławia, Wrocław. 